See discussions, stats, and author profiles for this publication at: https://www.researchgate.net/publication/329604749

\title{
Populism and Democracy: An Ambiguous Relationship
}

Article in SSRN Electronic Journal · January 2018

DOI: 10.2139/ssn. 3293005

CITATIONS

READS

15

1 author:

Emmanouil Mavrozacharakis

University of Crete

78 PUBLICATIONS 22 CITATIONS

SEE PROFILE

Some of the authors of this publication are also working on these related projects:

Changing Contours of Greek Politics Crisis, Institutions, and Electoral Politics in Hard Times View project 


\title{
Populism and Democracy: An Ambiguous Relationship
}

\author{
Emmanuel Mavrozacharakis \\ Centre for Human Rights (KEADIK) \\ Department of Political Science \\ University of Crete \\ Greece
}

\begin{abstract}
The question of the link between populism and democracy is a crucial one and for this purpose this paper will attempt to illustrate the relationship between the two phenomena. Firstly, populism and democracy will be approached from the point of political theory. Secondly, there will be an attempt to present the ambiguity of populism through a conceptual analysis. In the scientific research on the phenomenon of populism, there is still a lack of consensus on the way that populism should ultimately be evaluated from a democratic point of view. However, on the contrary to the negative notion of populism, democracy is associated with clearly positive attitudes. In this sense, the problem of populism is linked to political science with more disreputable manifestations of the political phenomenon. But the dividing line between populism and legitimate democratic confrontation is simply too vague. Populism affects democracy and vice versa. It is not easy to design an absolute dividing line between the two phenomena. However, the reference to the people plays an important role in the controversial form of expression of populism. From this point of view, in this paper there will be an attempt to analyze the fundamental distinctions between democracy and populism, by studying the characteristics of populism that have an actual positive impact on democracy as well as the opportunities and useful corrective elements it offers to it. On the contrary, criticism will be attempted to the arguments that consider populism as a corrective element in the quality of democracy, considering that it facilitates the inclusion of marginalized social groups, as well as side-by-side arguments that consider populism as a tool which can be considered as a positive aspect for democracy.
\end{abstract}

Keywords: populism, democracy

\section{@) $\odot \Theta \Theta$}

This work is licensed under a Creative Commons Attribution-NonCommercial-NoDerivatives 4.0 International License.

Corresponding Author: Emmanuel Mavrozaacharakis, Doctoral Candidate, Researcher

Affiliation: Centre for Human Rights (KEADIK), Department of Political Science, University of Crete

Address: Rethymnos

e-mail: mavrozaharakis@gmail.com

Copyright @ 2018,Emmanuel Mavrozaacharakis

European Quarterly of Political Attitudes and Mentalities - EQPAM, Volume 7, No.4, October 2018, pp.19-35.

ISSN $2285-4916$

ISSN-L $2285-4916$ 


\section{Introduction}

The multidimensional economic crisis in Europe has been a lucrative ground for the rise of Populism and the introduction of extreme and sometimes antidemocratic political arguments in the public discourse. Several political parties that traditionally had limited appeal, were reinforced in the midst of an undemocratic and anti-European rhetoric integrated in the context of a conscious attempt to create a symbolic enemy (Fehr: 2014, 415-416). The final aim of the populist project was to gather the growing number of frustrated voters, who were the first that suffered from the effects of the drastic social and economic consequences of the crisis (Priester: 2012).

On the other side, the established traditional democratic and progressive parties essentially accepted the role of the right\&left-wing populist space, as a front against the system, without questioning its themes and without making clear the differences of populism with the broader democratic area (Habermas: 2016). However, the populist agenda was predictable and simplistic, since the rising parties of far-right and far-left populism have emphasized the negative socioeconomic consequences of the financial crisis that is plaguing Europe with increased levels of social problems, inequality and social exclusion (Schäfer-Streeck: 2013; Kadrizke: 2009).

At the same time, the restrictive policies that emerged as a policy recipe for dealing with the crisis have rather disrupted the welfare state and therefore its stabilizing role (Woo \& Bova \& Kinda, \& Sophia Zhang: 2013). As Tony Judt asserts

"we have entered an age of fear. Insecurity is once again an active ingredient of political life in Western democracies. Insecurity born of terrorism, but also, and more insidiously, fear of the uncontrollable speed of change, fear of the loss of employment, fear of losing ground to others in an increasingly unequal distribution of resources, fear of losing control of the circumstances and routines of our daily life. And, perhaps above all, fear that it is not just we who can no longer shape our lives but that those in authority have also lost control, to forces beyond their reach"

(Judt: 2010, 217)

"(...) We have entered an age of insecurity - economic insecurity, physical insecurity, political insecurity. The fact that we are largely unaware of this small comfort: few in 1914 predicted the utter collapse of their world and the economic and political catastrophes that followed. Insecurity breeds fear. And fear - fear of change, fear of decline, fear of strangers and an unfamiliar world - is corroding the trust and interdependence on which civil societies rest"

(Judt: 2010, 33).

In any case, the diversity of crises that Europe faces today exposes the continent strongly to forces that are trying to produce a seemingly comprehensive and universal agenda of questioning the European Project at all

"We're witnessing the accumulation of various crises that are rapidly putting the whole European project under tremendous pressure. Illiberal forces are on the rise. Middle classes are shrinking. There's populist hatred of 'the establishment' and fascination with strong leaders. Europe is suffering from multimorbidity. Our problems, and the promises that are being broken, are now far greater than anything money could possibly buy, even if large sums of EU transfer funds were suddenly made available, and spent wisely, in a spirit of solidarity (...) Populist movements and parties, (...), are trying to stir up public trouble by stringing together the problems of stagnation, refugees and threats of terrorism into a single story. (...) Their simple- 
minded story-telling must be resisted. In this deteriorating European crisis, as far as intellect and politics are concerned, the recognition of the complexities of the multiple dynamics really matters'

(Offe: 2017)

Phenomena such as the financial crisis, frequent or serious cases of corruption, ineffective institutions, visible violations against the declared principle of equal treatment, promote and increase the tendencies of frustration and indignation. The widespread indifference today, the yearning for a strong leader, signs of social Darwinism and xenophobia, the mutual alienation between the political class and the rest of the citizens, is the consequence. This is exactly the wind with which the populists sail (Van Kessel: 2016, 158-160). In particular, this means that in order to gain power, populist parties are based on citizens who either lack experience with representative democracy or are deeply frustrated by it. In this context the cultivation of negative emotions plays a major political role (Rico\&Guinjoan\&Anduiza: 2017; Levinger: 2017). Especially Fear is expected to be the main emotional driver of populism.

The connection between populism and emotions is precisely described by Fieschi and Heywood $(2004,291)$ :

"populism relies, above all else, on an emotional appeal. It plays on a variety of emotions: anger, outrage, disgust, a sense of betrayal, a sense of loyalty. While the same may be true of other mobilisational devices, populism does so in a manner that is more direct and thus more strident. It appeals to what some Americans would call 'gut' politics, and does so unashamedly. In fact, populism defines itself in part by accepting this emotional, non- intellectual characterisation, which helps it remain on the outside of mainstream politics".

Today, several studies emphasize the widespread of fears along the population in the EU countries, namely a fear of losing their welfare and the fear of losing their own cultural identity (Glatzer 2015, 857-861; Special Eurobarometer 413, 2014; De Vries \& Hoffmann, 2017). The way in which political forces cope with the widespread negative feelings of the population by appeasing or intensifying mass aggression against any social groups is by itself already a criterion of a democratic or an antidemocratic stance. In other words, the use of emotions to preserve the dynamic contrast we vs. others is simply undemocratic.

In any case, with the entry of populist political formations, the political field of our era seems to have become more dynamic, pluralistic and clearly much more confusing, insofar as states face a future that is more open than ever and the Interdependence inside and outside of their national borders is growing.

Nevertheless, this prospect is combined with an increasing social insecurity that creates massive phobias in combination with negative attitudes towards the existing social and political order. The result is a rapid decline in the acceptance of the current public policies and a rising appeal of populist political proposals. In a strong sense, populism is at one side a threat to liberal democracy that comes «through the proliferation of corrosive political debates on issues such as immigration, Europe and welfare, putting pressure on mainstream political parties to react and move in line with their discourse» and at the other side a corrective

"as a warning signal to parties and governments to revisit their approaches to governance and representation - as well as reconsidering their political and economic offers along the left-right axis"

(Mcternan\&Chwalitz: 2014). 
It is precisely at this point that the reasonable question arises what is populism and what its ideological characteristics are. What are the elements that determine its attractiveness and are compatible with democracy both as an idea and as a political regime?

Undoubtedly, populism is a political vision that has its own theorists (Postel: 2007, 3-5; 288). This vision is associated with the preference for specific action and communication strategies that under certain circumstances can be extremely successful. In any case, under the viewpoint of the present work however, the vision of populism is undemocratic and has inevitably an undemocratic effect.

\section{The Ideological Characteristics of Populism}

A general definition of populism was formulated by Margaret Canovan $(1999,3)$ who defines it as

"an appeal to 'the people' against both the established structure of power and the dominant ideas and values of the society".

This approach connects the populism with anti-regime attributes instigated from negative sentiments as fear, indignation, disappointment but also prejudices against certain social and ethnic groups. The ideological core of populism coincides with a concrete conception of the idea of "the people" and "the relationship between people and politicians. In this respect "the people" becomes perceptible as a a homogeneous collectiveness.

Any political action must be oriented toward the will of this homogenous community. However, the populists shape a virtual conception of the will of the people (Eco: 2007, 106-138). This virtual construction is strengthened to have a duration in time followed by a further virtual construction, namely the dialectic of "we" (the people) against the "other" (the enemies). In other words, populist rhetoric both in its form and in its content openly challenges society since it only knows the division between "good" and "bad" among which a dialogue is impossible (Olschanski: 2017, 28).

Ignoring the normative-rational patterns to which classical political discourse is subject, the populist discourse is above all a narrative about an enemy, an attempt to prove his hostility, and a rhetorical battle against the enemy (Olschanski: 2017,77 ) . The image is constantly being projected, according to which the romance of the homeland is threatened and declining, and the suspected enemy is responsible for it.

The populists defend the "general will" of ordinary people against the corrupt elite (Mudde, 2004, 543; Mudde: 2007, 35) through the construction of "homogeneity" artificially through the preconception of cultural contrasts. The language is the tool through which homogeneity is created in populism (Decker: 2006). In particular, it is not a language that raises arguments but rather, it is a language that stimulates feelings, because through emotions people are mobilized collectively, especially when it is clearly defined who belongs and who does not belong to collectivity (Verhoeven \& Duyvendak: 2015, 2-6). Very important is the rhetorical expression of populism which should be caustic even if it is based on half-truths, erroneous arguments (fallacies) or even on false news (fakenews) (Daase \& Deitelhoff: 2017). Hence, Kenneth Minogue (1969; 208-209) emphasized early the "intellectual emptiness of populist movements," arguing that populism does not "have an ideology in any serious sense, merely a rhetoric" and Margaret Canovan viewed Populism as "a rhetorical style which relies heavily upon appeals to the people" (Canovan 1984: 313). In any case, however, "Manicheism" is the cornerstone of populist rhetoric (Mudde: 2004,544; Priester: 2012). The dividing line between "we" and "others" can be adjusted by 
circumstance, but it must always exist because it produces the cohesion and consistency of the "people", as that part of society that claims sovereignty for itself.

The popular language is usually relaxed and warm to the inner audience and sharp outward. At the same time, intelligent and systematic use of propaganda is essential, which is not intended to better represent specific interests in the context of a social dialogue, but to shape public opinion and achieve maximum control over the citizens (Eco2017, 106-138).

From the collective recruitment of "we", there emanates a dislike to representative democracy or an emotional negation of its procedural representatives such as the mainstream parties, parliamentary committees, politicians, ministers, dignitaries, etc. This is so, because in this form of regimes, the political decisions and the control of the executive (government) are not exercised directly by the people, but by a popular delegation (parliament). Populism combines the dislike towards any representation with the suggestion that those who engage in parliamentary activities, and in particular government responsibility, have a tendency towards excessive self-interest, greed and corruption (Urbinati: 2014, 120-135).

In contrast to representation, populists propagate the unity between the people and the populist politicians and pretend to be the guardians of popular sovereignty and the representatives of the true will of the people. In this case, the populists elevate and spread without filters, the fundamental idea of liberal democracy that all power comes from the people. This position is accompanied by the reluctance of populists to compromise, considering that any form of compromise distorts the true will of the people. Consequently, compromises are rejected as a deviation from the ideal of pure "popular sovereignty". This intransigence of most populist parties towards consensus and compromise is itself a vertical opposition to democratic conciliation.

Populists do not promote the democratic dialogue in the search of consent, but pursue and institutionalize the discontent, the resentments, the fears and the hopes of the citizens by means of a mythverbalism, which directly addresses the feelings and skillfully exploits them. Hopes are aroused by the dispersion of simplistic, unrealistic-popular solutions (Kotroyannos: 2016, 25).

Particularly vulnerable to populist slogans are middle class members who feel that their existence is threatened, not only by the global economic crisis but also by the mass influx - often illegal - of Muslim immigrants: the fear of a creeping islamization process.

In the context of the common image of the enemy the American and the European populists have serious differences. American populists cultivate a strong aversion to the welfare state, against the European standards and generally against a strong state (Kazin: 2011, 106; Rosenthal: 2016). They therefore reject the tax increases strictly from the outset, by strengthening an antitax fetishism (Tea Party, Conservative Party), which dates from the time of President Reagan in the 1980s and is associated with a strong anti-state rhetoric (Rosenthal: 2016). This rhetoric has been associated with President Obama's political challenge, in particular with the argument that he is allegedly trying to introduce socialism into the United States, or even worse, communism. In this context, there was deliberately cultivated the suspicion that President Obama is a stranger with Muslim roots, even a secret agent of Islam (Rosenthal: 2016; De la Torre: 2017). On the contrary, the anger of the European populists is directed against European integration, namely against the European Union and its institutions (Kotroyannos \& Mavrozacharakis: 2018, 15-17). The starting point of this polemic is the widespread dissatisfaction in Europe, which is based on a simple reasoning. This reasoning is that in the current debt crisis, the rich EU countries that have stable economies prudently managed their finances and now pay for those countries that have overwhelmed huge debts and are in danger of bankruptcy because they have gone beyond their capacities. 
In any case, combining the attributes of populism set out in the literature, it is possible to identify ten basic features: (1) Populism as an ideology lacking core value; (2) anti-elitism; (3) the hostility to representative politics; (4) a mobilization against the political status-quo (5) the personal appeal to the people; (6) the homogeneity of the people; (7) the ethnic and cultural discrimination; (8) the idealization of the "heartland"; (9) a sense of perceived crisis; and (10) a context dependent and self-limiting phenomenon (Vittori: 2017, 54-56).

From the standpoint of ideological approach, populism can be defined "as a thin-centered ideology that incorporates two necessary attributes, anti-elitism and the criticism of political representation (Vittori : 217,59). Concerning the criticism of political representation:

"it may be directed against the classical horizontal left-and-right division. Populists challenge the classical horizontal axis of the political division (left and right), focusing instead on the vertical axis, which divides between the powerful few and the people. Albeit parties which incorporate a populist ideology may be placed in the left or the right spectrum of the division, populism in itself is neutral to this distinction. .... Moreover, populists reject the Weberian professionalization of politics. Albeit being frequently undetermined, one of the most salient issue in the populist discourse is the radical transformation of both the political class and, particularly, the parties' bureaucracy, the so-called Party in Central Office"

(Vittori: 2017, 58)

\section{Democracy and Populism. An ambiguous relationship}

In any case, populism coexists with democracy in the context of a difficult but real relationship. The urgent question is therefore what exactly is the relationship between populism and democracy. In the scientific research on the phenomenon of populism, there is still no full consensus on the way in which the populism must ultimately be evaluated from a democratic standpoint.

Some theorists believe that populism has a democratic impulse, others believe that it poses a threat to democracy, whereas others consider that it is both a risk and a corrective element for Democracy (Bryder: 2009, 9-14)

According to Exampel in Abts and Rummens, democracy is based on the idea of open and diverse society, integrated on a political stage and populism is based on a closed, collective identity, which represses individuality (Abts \& Rummens, 2007: 415). In these sense, it appears that populism can be seen only as a threat to the existence of democracy. In one other sense, according to Ackermann $(2003,154)$ for example, the challenge posed by populism parties can promote and stabilize democracy, a potentially good effect that can be perceived as functional for a healthy democracy because it forces elites to open up for party competition and broadens their political agenda (Akkerman, 2003:154).

Some authors insist that

"Populism is what we have when elites lose their ability to engage in democratic politics and fail to adjust them to the social changes, which call for ongoing adaptations....Populism .....reflects the necessity of adaptation following a change. Populism is an evolutionary political concept; it warns that the balance has been upset and that a new set of political ideas, plans, and actions is needed"

(Vittorio: 2017, 137)

This position assumes that populism, to some extent, turns the attention of citizens to public affairs while offering some motivation for action. In this sense populism serves the democratic principle of participation and active presence in the public space. This argument is, however, superfluous because it 
ignores the aggressiveness of the populists against the established democratic institutions such as the traditional parties, the parliaments and their procedural functions, the democratic dialogue, the search for consensus, the respect of the opposite views etc. Consequently, there are fundamental distinctions between democracy and populism, and even a few features of populism actually have a positive effect as corrective elements in democracy.In this context, apart from the obvious electoral shifts in favor of the parties expressing populism, it has not been proven by any empirical research that populism acts as a corrective element on the quality of democracy, facilitating the integration and inclusion of marginalized groups of people. Arguments therefore claiming that the inclusion attribute of populism has a positive effect on democracy, and in particular that populism can give voice to groups that do not think they are properly represented or represented by the elites (Mudde \& Kaltwasser: 2012, 21) is at least fictitious. More fictitious, however, is the argument that populism raises issues which affect the implicit majority and express it, such as for instance, the issues relating to refugee and immigration which may contribute to Democratic dialogue (Mudde\&Kaltwaaser: 2012, 21). In this sense, populism probably addresses, represents and mobilizes excluded groups of society, but this does not mean that it improves their political integration, despite the fact that it raises issues that concern them.

The fact that the growing presence of populism on the political level is a clear sign of the crisis of democracy means that at a theoretical level, there exists an actual reason to approach populism as a serious threat. This threat no longer concerns only the dimension of electoral expansion but, overall, the latent and universal questioning of the historical democratic institutional and legal culture.

In this context it is useful to note, that the second half of the 20th century was marked by a competition between different social-political systems. From this controversy, which often took on the dimensions of extreme conflict, the democratically legitimized constitutional state of the Western world emerged as a triumphant winner, erasing a successful course of decades of peace and freedom. The party systems of the Western democracies with their persistent and compact stability managed to harness the extremist tendencies of all forms. Nowadays, however, traditional dividing lines are increasingly losing their importance because of political upheavals that bring populist political forces to the forefront. Populist parties and movements penetrated dynamically in almost all Western democracies, becoming an integral part of party systems. At the same time, an intense debate about hatred and fear, democracy and freedom, security, terrorism and immigration is being diffused everywhere. Precisely the foundations of freedom, which have been seen as a constant facts for decades, are seriously under threat.

Therefore, the imperative question arises as to whether the range of populism with its authoritarian dimensions seriously threatens liberal societies. The Brexit in Great Britain, the election of Donald Trump as President of the USA, the rise of Le Pen's radical party in France, the rise of the five-Star Movement in Italy, the rise of far-right political groups in Eastern Europe, in Austria and Germany, and not least the rise and cooptation in power of left wing and far-right populism in Greece are very clear indications that democracy today is facing a huge ordeal. Populism seems to triumph over logic by creating a blow to liberal western values (Roth: 2017).

In almost all cases of countries with populist political figures, their course is very successful and continues to grow dynamically (Roth: 2017). The populism never almost manifests itself openly with antidemocratic positions, but always adheres to democratic pretensions. In other words, even in extreme forms of political systems, there are no populists expressing themselves against democracy. With a paraphrase of Clausewitz, one could say that populism is the continuation of dictatorship by democratic means (Damböck: 2017, 79-80). A propaganda stance against democracy as it was probable and normal in the nineteenth century is currently considered to be totally unprofitable and impossible. An open attitude towards democracy is now considered a political suicide, even if citizens' attitudes to Western democracies are 
increasingly ambiguous in terms of the effectiveness, functionality and scope of democratic governance today.

These considerations refer to a fundamental difference between genuine democratic and populist policy, which is found at the level of political style. Democratic policy is related to a clear and pragmatic language grounded to factual data. The facts are put on the table and opinions are expressed on this basis. Populism, on the contrary, is the art of reversing and masking events as well as justifying opinions through their distortion in sequence with a management of the whole process that diffuses the impression of a clear speech. It is a political method contrary to the democratic one. The political content of populism develops through the method.

The programs of populist parties reflect precisely this - the populist style of distortion, reversal and masking of facts and factual data - which makes the real difference with respect to democratic parties. The ambivalent manipulation of democracy-the reflection of democracy in its opposite, remains a visible dimension of the populism from the starting point to the endpoint leading to a characteristic paranoid mixture of ideas which ultimately reveals the Inherent inconsistency of objectives from which populism is possessed. The refractive reflection of democracy that characterizes populism is an indication that many supporters follow it only temporarily or by mistake and that populist policies contain an irregular form of appearance that is able to deduce the alleged real goals and the opposite of them in the same field of populist politics. Along with the anti-elitist attitude and the deforming prism on democracy, populism is based on a strict requirement of exclusive representation of the people, especially through the voice of the leader. Protectionism thus becomes the real driving force of populism. "In a similar manner to the totalitarian models defeated in 1945, populism is strictly against the elites, but in contrast to fascism and communism, populism does not theoretically challenge democracy but attempts to transform a mass society into a homogeneous and therefore politically active entity". Populism is in other words a shadow of representation and modern democracy (Canovan: 1999, 12) in the sense that it acts as a corrective method or at least a reaction to elitist democratic institutions and modes of representation.

Populism attempts to control all the critical functions of the system and to reform the constitutional framework towards more authoritarian directions. "The constitution ceases to be a framework for policy making and turns into a purely party instrument aimed at occupation of the state" (Müller: 2017, 111).

The imperative requirement of command of populism makes the populist leader the only representative of public opinion. Only what the leader expresses is the will of the people, and only those who follow the leader tautologically belong to the people. The prophecy of the distinguished supporter group brings power to populist politicians and is rewarded with privileges at the expense of those who are excluded from the imperative mandate (Damböck: 2017, 81).

For the effective functionality of the artificial Division of society, Populists accuse the elites that they act against the centrality of the people, by claiming that they are arrogant, selfish and incompetent. In this sense, the political establishment is depicted as the enemy of the people, and establishment parties have no idea of what ordinary people find important or what policy reforms they would like to see implemented. Establishment parties can be considered "all those parties that have participated in government or that the governing parties regard as suitable partners for government formation; those parties that are willing to cooperate with the main governing parties by joining them in a coalition government" (Abedi, 2004, p. 6).

The above critical remarks supports the view that populism ultimately coexists with, but defies democracy. Those who claim that populism is helping democracy should ask themselves what democracy ultimately is. A democratic consensus implies that people want to live together and agree to express their sovereignty according to certain principles and through certain channels - institutions. This is a 
"representative" democracy. Democratic systems can only exist when citizens internalize and share a democratic culture, and participate in the life of the "state" (Res Publica).

The foundations of this democratic civilization are the equality in the law of all people living in one country, the clean separation of legal forms of power, the open social dialogue as a means of tackling conflicts of interest and social Cohesion. All this is much more than fine words: if these principles are not respected, then democracy will inevitably be overthrown even if its classical institutions remain.

\section{The Dimension of Post-factum}

The dynamic of the populists, which undoubtedly poses a serious threat to liberal democracy, is linked to many Authors with the post-factum era, the time after the truth (Lepore: 2016). This post-factum term signifies a profound political change in our society, underlining that populism enhances political action and thinking that no longer focus on facts and data but on lies, on unfounded Promises and disorientation of public opinion from the essence of things (Lepore: 2016). Democracy enters in an post-factum situation when facts and evidence are no longer used on public debate and politics, but some popular narratives. In a post-real democracy, facts and evidence lose their prestige and from that moment onwards ignorance and concealment of events can bring political success (Hendricks \& Vestergaards: 2017).

Of course, a golden age of democracy, in which politicians were absolutely honest and authentic, never existed. Politics has always been a somewhat amoral if not dirty business, with a significant degree of deception as intrinsic elements ,that however, never came openly to the surface (Marschall: 2017). The innovation of post-factum democracy is however that the exponents of populism do not even bother to hide the lie or to support their contradictions with some verifiable facts (Hendricks \& Vestergaards: 2017) . Anyone exposed by them to a lie has no fear of consequences to the extent that he is able to successfully blame those who revealed the lie, that they themselves lie and are not trustworthy (Hendricks \& Vestergaards: 2017).

According to Wolfgang Streeck, from the perspective of neo-liberal narration «the post-factual age began as late as 2016, the year of the Brexit referendum and the smashing of Clintonism by Donald Trump._Only with the collapse of post-democracy, and the end of mass patience with the 'narratives' of a globalization that in the US had benefited in its final years only the top 1 per cent, did the guardians of the dominant 'discourse' call for obligatory fact-checking. Only then did they regret the deficits experienced by those caught in the pincer grip of the global attention economy on the one hand and the cost-cutting in the education and training sector on the other. It is at that point that they began to call for 'eligibility tests' of various kinds as a prerequisite for citizens being allowed to exercise their right to vote._The fact that the Great Unwashed, who for so long had helped promote the progress of capitalism by passing their time with the Twitter feeds of Kim Kardashian, Selena Gomez, Justin Bieber e tutti quanti, had now returned to the voting booth, was registered as a sign of an ominous regression (Streeck :2017,9).

When, for example, some Media that try to reveal lies, are successfully accused of bias in favour of a party area, or if voters do not trust them, then the disclosure of falsehood does not imply any serious consequences in terms of regression in political career or the reputation of a political person lying. In the post-factum democracy, it is of secondary value to follow the events (Hendricks \& Vestergaards: 2017).

Surely the quest for truth is a matter of controversy and negotiation, which is the trademark of the free societies in which neither the Church nor the Sovereign determines the direction but responsible citizens decide how they would like to live together. Democratic belief means that to believe that something is real must be proved. With the populism's advance the factual proof as a driving force of human actions is disputed. There is varied evidence of this. First of all, let's examine Greece, which faced a real public debt problem that emerged only from 2007 onwards, while it was previously masked by all the guiding political 
leaders and political parties. When the dimension of debt came to the surface, its substance was challenged by forces adjacent to both left and right populism with arguments beyond any logic. Rewarded in essence for their hypocritical attitude and for their unholy cooptation, these forces of the extreme left and the extreme even came to power, where they faced the reality of the debt. Another tangible example is the United States, where a candidate, who has blatantly refused anthropogenic climate change, although 99\% of world scientists have no doubt about it, has emerged as president.

In Britain, the Brexit campaign won the referendum, although all economic institutes warned the Brexit would significantly harm the country. Therefore rationalism and his devotees are challenged by a variety of interest groups and apparently their influence on political events is declining (Felix: 2016). In Germany and other countries, right-wing populists are rising systematically by raising arguments against refugees and immigrants, while avoiding to negotiate the positive effects of the influx of foreigners on the treatment of the demographic problem and to fill the economic gap in unskilled labor.

The untruths now coexist with the truth in the public debate and the faith is equated with knowledge. The practical principle of all dictators, to present everyone as corrupt, cunning, hypocrites who draw attention to unpleasant events, has now prevailed in the Western democracies (Felix: 2016).

The reason for the extension of the field for non-real discourses is that in the complex world of technology is added the overall disorientation in the context of growing globalization (Wibmann: 2016).

In the daily news and forecasts there is asserted that there is no economic future. It makes sense that no one wants to hear these facts. The same is true in the political arena when a government seems to have lost control, then it is exposed to a crisis of confidence. It is not surprising, therefore, that those who revolve around the unreal, often prescribe a nostalgic world of the past. Putin, for example, dreams publicly of the re-establishment of the Russian Empire, Erdogan re-enacts the Osman Imperium, Trump promises to make America "big again", Brexiters nourish the craving for "lost England" and ISIS videos glorify a mythical caliphate.

According to Svetlana Boym (2001) the 21st Century is not characterized by the pursuit of innovation by but by the spread of nostalgia which undermines critical thinking in favor of an emotional association.

"It is the promise to rebuild the ideal home that lies at the core of many powerful ideologies of today, tempting us to relinquish critical thinking for emotional bonding. The danger of nostalgia is that it tends to confuse the actual home with an imaginary one. In extreme cases, it can create a phantom homeland, for the sake of which one is ready to die or kill. Unelected nostalgia breeds monsters. Yet the sentiment itself, the mourning of displacement and temporal irreversibility, is at the very core of the modern condition"

$$
\text { (Boym: 2001, XV-XVI). }
$$

Through a post-factum discourse, populism declares liberation. The rejection of factual events and elements considered the most significant symbols of knowledge and education is surrounded with a youthful euphoria and with a revolutionary fascination. Hence many Trump-style populist movements are presented as enthusiastic ventures and as "a people's insurrection against the establishment" (Priester: 2012). The insistence on the truth on the other seems a boring, obsolete, old-fashioned process. Controlling, questioning, and finding are often hard work and have no charm. But precisely these elements represent the maturity of the Enlightenment that Immanuel Kant claims. A post-real world is not a progress but a return to the dark days and they are presented by the populists as bright. 


\section{The Power of Populism}

Increasingly, the term populism has been subject to a kind of general condemnation in recent decades. The populists are isolated and marginalised in the political scene by established political actors accused in the public debate as fundamental opponents of the political establishment and arsonists of the Republic (Kleger: 2016, 97-103). As Ranciere (2017) notes, the Government elites and its ideologists, i.e. the dominant political discourse, distinguish in populism three key traits:

1) a style of interlocution that addresses the people directly, going around its representatives and its notables

2) the claim that governments and ruling elites are more concerned with their own interests than the res publica

3) an identitarian rhetoric that expresses fear and rejection of foreigners.

The populists are drawn from the negative side of the battlefield, proclaiming the establishment as the highest enemy or even more simply arguing "for the return of power to ordinary people" (Boyte: $1986,3)$. In this sense the power of populism is inherent in the very phenomenon of the people as an element of the constitutional order. As Ranciere (2017) notes:

"Our constitutions themselves assert the existence of an entity called the people, which is the source of power and the privileged interlocutor of political discourse. This was the same conviction that the republican and socialist orators of yesteryear elaborated, with no hidden agenda. This is not bound to any form of racist or xenophobic sentiment. It does not take any demagogy to assert the claim that our politicians think more about their careers than the future prospects of their fellow citizens and that our rulers live in symbiosis with the representatives of big financial interests. The same press that attacks the "populist" drift day after day offers us the most detailed proof of this. For their part, heads of state and government sometimes accused of populism, like Berlusconi or Sarkozy, steer well clear of propagating the "populist" idea that the elites are corrupt"

In addition to the systematic reference to the people, an important element that lends dynamism to the populism is the dimension of the inclusion and integration of marginalized and inferior social groups. In the international bibliography it is common to distinguish between exclusive and inclusive populism (Mudde \& Kaltwasser: 2013, 147-174). Perhaps the issue of exclusion and integration is the most crucial aspect of the relationship between populism and democracy. In this context, the three dimensions of the material, political and symbolic exclusion-inclusion play the most important role (Mudde \& Kaltwasser: 2013, 158). The material dimension refers to the allocation of public funds and resources, for example jobs for different social groups. In the case of material exclusion, certain groups are excluded from accessing public funds. Material inclusion, as such, is not particularly populist. In fact, it is part of the welfare state. In many cases, however, it forms a part of a customer policy and is therefore linked in some form to populism (Mudde \& Kaltwasser; 2013, S. 158).

The political dimension refers to the two dimensions of democracy according to Robert Dahl. On the one hand, there is the dimension of political participation and, on the other, the dimension of public policy disagreement on specific issues. Political exclusion means here that some groups are hindered in political participation in the democratic system and are not represented in public disputes. In most cases, these groups previously had the right to participate and represent themselves, but were ignored by the political establishment (Mudde \& Kaltwasser: 2013, 161).

The symbolic dimension sets the boundaries between the people and the elites in terms of populism. At the same time, groups explicitly included in the definition of the people are surrounded by the collective term "we" and are therefore subject to a symbolic integration process (Mudde \& Kaltwasser, 2013, 164). 
Empirically, one could represent the comparison between inclusive\& participatory and exclusive \& non-participatory populism differentiating from them from leftwing populist formations like the Greek Syriza, the Spanish Podemos, French PG of Melanson and the Italian Five Star Movement and on the other farright populist formations like FPÖ in Austria, FN in France under Le Pen or AFD in Germany. The left-wing populist formations in material, political, and symbolic way, are typically participatory by attempting to promote political programs that improve in some way the quality of life of some weak and poor social groups and migrants while, on the contrary, far-right groups use more the exclusion dimension, particularly with regard to migrants. In a sense, the left-wing populist formations, of southern Europe in particular, behave according to the Latin American model of populism that deals with societies that do not have the level of equalization and prosperity of Western Europe. This does not mean that there are no acute socioeconomic differences in Western Europe as well. However, the weakest social groups still rely on more or less extensive social services and aids and enjoy full political right. Like the populists in Latin America, who are struggling for better living conditions of the population (Mudde \& Kaltwasser $(2013,159)$, left-wing populism of southern Europe also behaves more explicitly about the excluded, the marginalized and the underprivileged. Nationalist populism instead sets itself the primary objective of protecting the already existing good living conditions and the people from the supposed ever-increasing risk of foreign refugees and immigrants. Therefore material focus is more concentrated on excluding outside groups rather than on the inclusion of weak groups of the people (Mudde \& Kaltwasser: 2013, 160).

The European far-right populism is more interested in the native population and does not consider free elections to be sufficient, as the established parties do not allow the real people to express themselves with their vote on issues of European migration and Integration. The far right parties, however, are gaining their electoral influence primarily through a policy of excluding foreigners and less through a policy that promises the people economic and social advantages. The exclusion of others has always been at the heart of extreme right in Europe. As Mudde \& Kaltwasser points out, Europe's right-wing populists support an ethnocentrism or a national democracy based on a distinct national culture (Mudde \& Kaltwasser: 2013, 163f).

As Held \& Mcnally (2016) assert,

"One of the paradoxes of this period is that discontent and uncertainty amongst the working class has been most successfully co-opted by the right. The right has understood the extent of the fury, the fear of loss of standing, the anxiety about 'others', and the need to blame something or someone else.. While some figures on the left ....... have grasped this and tried to interpolate the anger and frustration into a progressive movement, the liberal establishment has been behind the curve and failed to offer a cathartic political vision for the future. One reason for this is that the liberal centre typically focuses on the complexity of policy issues ahead and has failed to match its policy prescriptions with political instinct and acumen; its professionals and experts want to dwell on the evidence which justifies their positions but fewer and fewer voters are in the mood to listen as the appetite for fact is replaced with emotion and a call to arms. There is wide gap between policy and politics. The centre-left establishment has been preoccupied with governance and the specifics of policy; whilst the right has embraced protest politics too often void of substantive policy, railing against the 'establishment' at every turn"

\section{Conclusion: Democracy and Populism Are Two Incompatible Concepts}

The real danger stemming from populism is that the slogans of the populists are acting like an infectious virus. This means that even politicians belonging to the so-called large established parties are easily attracted to the use of populist slogans. Politics then takes the tone of a farce with tangled roles and a 
blurry scenario. We see in Greece, for example, Golden Dawn to use the slogan "Greece belongs to the Greeks", belonging to the once powerful socialist of PASOK-Party Andreas Papandreou. We see, on the other hand, politicians belonging to the main opposition, who once wanted to refer to Andreas Papandreou to the special courts, today to defend the proceedings of his governments. Roles are easily reversed.

The former opponents become devotees and the devotees easily opponents according to the political stream. There is a tendency across Europe that many members of the ' political establishment ' are often tempted to adopt Eurosceptic positions of the populists. Instead of reinforcing the EU's ability to manage crises through the reinforcement of supranational European institutions, they strengthen the nation-state bastions. That is precisely what the populists demand.

There is a tendency for many members of the

"political establishment" across Europe to adopt the Eurosceptic positions of the populists. Instead of reinforcing the EU's crisis management capacity by strengthening transnational European institutions, they strengthen the nation-state bastions. That is precisely what the populists demand. It is evident that populism expresses the political and ideological absurdity of the crisis era, to the extent that its relationship to democracy has become inconspicuous and blurred. This is obvious from the fact that it is not generally accepted in the scientific debate that populism is an obvious danger to democracy and many are trying to refute the argument that populism should be perceived as «an absurd reversal of the ideals and processes of representative democracy"

(Rosanvallon: 2011)

Populism "is both the symptom of a real distress and the expression of hope. It was born out of a crisis. It does not only express an inherent evil. It is the meeting point between political disillusion - caused by a lack of representation, a malfunctioning democratic regime and the connection between that disillusion and social disarray, linked to the failure to resolve the social question today - and people's increased awareness of their impotence, the absence of alternatives and the opacity of the resulting world. From this perspective, populism can be understood as a kind of simplistic, perverse response to these difficulties"

(Rosanvallon: 2011).

However, there is increasingly established the position that populism is the only genuine form of democracy to the extent that it achieves the emergence and mobilization of the excluded sections of society and contributes to a "democratization of democracy" (Laclau: 2005, 168-170). This point of view refers implicitly to an extensive interpretation of democratic laws and institutions in the name of the founding principle of majority and the motto "fair is the law of many". Minorities must either be silenced by obedience or disappear.

However, the substance of populism is dominated by a "moral manicheism" with the arbitrary separation of the social body in the "good" (the weak, the poor, the Patriots, the religious, the working people etc. ) and the "bad" people (the few, the strong, the rich, the educated, the Elite). This simplistic interpretation of reality leads to a dangerous division of society in which there is no place for dialogue and consensus because the hatred of the "we" towards the "others" is triggered.

With this technique, populism produces an identity for the excluded, constructing an enemy. Thus, for the victims of populism, the symbolic reality prevails over the physical reality. Realism is lost and fantacies of an enemy that threatens the happiness of simple people prevails. Moreover, the addiction to the constant search for enemies, the demonization, the grudge and the simplification of reality erode political rationalism and social dialogue. 
The populist leaders established their power on the intrigues, fantasies, phobias, insecurities and internal conflicts of each individual especially in the time of crisis. The divided and unsecure "ego" of these individuals seeks a reference point for building an identity. That is why the leader invents the "other", the "enemy" and cultivates both individual and collective narcissism. Hate towards the "engineered" enemy warms the narcissism and makes the person strong. In essence, populism nourishes the individual's uncertainty and builds its power on it. As a result, there is created the collective delusion for the prospect of easy solutions by the leader-Messiah and the denial of the individual responsibility. The citizen ceases to operate autonomously and seeks the certainty of mass. The herd - man is the eminent political type of populism. The populism, therefore, by its nature, undermines the essence of democracy.

Democracy is based on free and critical political participation, while populism promotes "emblematic" political participation. Democracy makes the citizen self-reliant, investing in their autonomous will, while populism embraces him in the kingdom of heteronomy and dependency. Democracy abhors demagogy, favors ideological purity and political emancipation, uses dialogue, and denies the myths of messianism. All this, however, is canceled by populism, because it is as a thin-centered ideology, which has a "chameleonic" character (Taggart 2002: 70), it favors demagogy and propaganda, it aims at political and ideological manipulation and highlights the messianic character of political leaders.

Democracy and populism are two incompatible concepts, so populism is blossoming where democracy has problems of dysfunction. Obviously, it is difficult to refer to democracy without taking into account populism, especially as it attracts and mobilizes a wide range of citizens across Europe, and in this sense it can be seen as an integral mirror of democracy (Pianniza: 2005). However, it is impossible to protect democracy with the use of populism as an ideology that disputed the democratic forms and procedures and in this sense the mass spreading of populism can be a process of overthrowing, leading to a further generalization of conflicts, violence and ultimately the emergence of totalitarian tendencies.

\section{References}

Abedi, A. (2004) Anti-Political Establishment parties. A comparative analysis. New York, Routledge.

Abts, K., Rummens, S. (2007) Populism versus Democracy. Political Studies, 55(2), pp. 405-424.

Akkerman, T. (2003). Populism and democracy: challenge or pathology?, Acta Politica,pp. 147-159.

Boym, S. (2001) The Future of Nostalgia, Basic Books, New York.

Boyte, H.C. (1986): The new Populism. Philadelphia

Eco, U. (2007): Im Krebsgang voran. Heiße Kriege und medialer Populismus. München: Hanser.

Bryder, T (2009) Populism - a threat or a challenge for the democratic system?, Course title: Xenophobia, Politics and Right Wing Populism in Europe University of Copenhagen, Faculty of Social Science, Department of Political Science. Available

https://politicalscience.ku.dk/international_students/present_international_students/taking_exams/past_papers/Po pulism a threat_or_a challenge for the democratic system.pdf(Accessed: 10/09/2018)

Canovan, M.( 1984). People, Politicians and Populism, Government and Opposition, 19 (3), pp. 312-327

Canovan, Margaret (1999) Trust the People! Populism and the Two Faces of Democracy', Political Studies 47, pp. 2-16.

Damböck, C. (2017) Demokratie kontra Populismus. Eine nonkognitive Sicht. Available at:https://homepage.univie.ac.at/christian.damboeck/texte/1933_2017.pdf (Accessed:20/09/2018)

Decker, F. (2006) Die populistische Herausforderung, in: Frank Decker (Hrsg.), Populismus. Gefahr für die Demokratie oder nützliches Korrektiv?, 1. Auflage, Wiesbaden: Springer VS Verlag für Sozialwissenschaften, S. 9-32.

De la Torre, C. (2017) Trumpism and the future of democracy in America. Available at: https://www.clingendael.org/pub/2017/3/trumpism-and-democracyl (Accdessed: 14/09/2018) 
De Vries, C., Hoffmann, I. (2017) Fear not Values. Public opinion and the populist vote in Europe. Bertelsmann Stiftung. Available at: https://www.bertelsmannstiftung.de/fileadmin/files/user_upload/EZ_eupinions_Fear_Study_2016_ENG.pdf (Accessed: 04/09/2018)

Fehr, $H$ (2014): Eliten und zivile Gesellschaft: Legitimitätskonflikte in Ostmitteleuropa, Springer Fachmedien, Wiesbaden

Fieschi, C., Heywood, P. ( 2004) Trust, Cynicism and Populist Anti-politics, Journal of Political Ideologies 9 (3): pp. 289309.

Eco, U(2007): Im Krebsgang voran. Heiße Kriege und medialer Populismus. München: Hanser.

Felix, S (2016): "Postfaktisch":Das Wort des Jahres ist "falsch" Available at: http://www.zeit.de/kultur/201612/postfaktisch-wort-des-jahres-post-truth-demokratie-jill-lepore (Accessed: 30/01/2018)

Glatzer, W. (2015) Worries and pain - The dark side of quality of life. In W. Glatzer (Hrsg.), Global handbook of quality of life . Dordrecht: Springer Science+Business Media

Habermas, J (2016) : Für eine demokratische Polarisierung. Wie man dem Rechtspopulismus den Boden entzieht. Available at: https://www.blaetter.de/archiv/jahrgaenge/2016/november/fuer-eine-demokratische-polarisierung (Accessed: 2/9/2018)

Held, D/McNally, K (2016):Gold plated populism: Trump and the end of the liberal Order. Available at: https://www.opendemocracy.net/david-held-kyle-mcnally/gold-plated-populism-trump-and-end-of-liberal-order (Accessed:28/09/2018)

Hendricks,V. Nestergaard, M (2017): Verlorene Wirklichkeit? An der Schwelle zur postfaktischen Demokratie Available at: http://www.bpb.de/apuz/245212/verlorene-wirklichkeit-an-der-schwelle-zur postfaktischen-demokratie?p=all (Accessed: 31/01/2018)

Judt, T (2010) III Fares The Land: A Treatise On Our Present Discontents Penguin Books, London, New York, Toronto , Dublin, Victoria, New Delhi , Auckland, Johannesburg.

Kadritzke, U (2009) Die Krise, die längst da war -Finanzkrise und soziale Ungleichheiten. WDI-Mitteilungen 12, pp. 659666.

Kazin, M (2011) American Dreamers: How the Left Changed a Nation, Albert. A Knopf , New York.

Kleger, H (2016) : Öffentlichє Vernunft als Thema und Prozess-Bürgersouveränität, Protest und Populismus . In: Marquering, Stefan Wolf,Paul (2016), Unkritische Massen? Offene Gesellschaft und öffentliche Vernunft. Lit Verlag, Berlin, pp. 92-110.

Kotroyannos, D. (2016). Alexis Tsipras und der rhetorische Diskurs als Politik. Rethymno. Available at: https://mpra.ub.uni-muenchen.de/70926/ MPRA Paper No. 70926 (Accessed: 20/09/2018)

Kotroyannos, D.,/ Mavrozacharakis, E. (2018). Far-right populism and the role of democracy in Europe, European Quarterly of Political Attitudes and Mentalities, 7(3), pp. 10-25.

Laclau, E (2005) On Populist Reason. London/ New York

Levinger, M. (2017) Love, Fear, Anger: The Emotional Arc of Populist Rhetoric. Narrative and Conflict: Explorations in Theory and Practice, 6(1), p. 1-21. Available at: http://journals.gmu.edu/NandC/issue/view/202 (Accessed:20/09/218)

Machiavelli, N (1882) The Historical, Political, and Diplomatic Writings, Bd. 4: Diplomatic Missions 1506-1527, Boston 1882

Marschall, S. (2017) Lügen und Politik im "postfaktischen Zeitalter". Available at: http://www.bpb.de/apuz/245217/luegenund-politik-im-postfaktischen-zeitalter (Accessed:30/08/2018)

Mcternan, M/Chwalitz, C (2014): The populists: threat or corrective to the political establishment?. Available at: http://www.policy-

etwork.net/pno detail.aspx?ID=4550\&title=The+populists\%3a+threat+or+corrective+to+the+political+establishme nt\%3f (Accessed: 27/09/2018)

Minogue, K. (1969). "Populism as a political movement." In G. Ionescu, \& E. Gellner (Eds.), Populism: Its meaning and national characteris-tics (pp. 197-211). New York: Macmillan

Mudde, Cas (2004): 'The Populist Zeitgeist', Government and Opposition 39(4): 542-563

Mudde, C. (2007). Populist Radical Right Parties in Europe. Cambridge, MA: Cambridge University Press

Mudde, C/ Kaltwasser,R. (eds) (2012), Populism in Europe and the Americas: Threat or Corrective for Democracy? New York: Cambridge University Press.

Mudde, C/ Kaltwasser, C. R. (2013): Exclusionary vs. inclusionary populism: comparing contemporary Europe and Latin America, Government and Opposition, 48, 2: S. 147 - 174.

Müller, J-W(2017)What is Populism ( Ti einai laikismos) (In Greek) Edition Polis , Athens 
Offe, C (2017) 'Europe is suffering multi-morbidity': a conversation with Claus Offe in Berlin. Available at: https://theconversation.com/europe-is-suffering-multi-morbidity-a-conversation-with-claus-offe-in-berlin-71127 (Accessed: 6/9/2018)

Olschanski,R (2017): Der Wille zum Feind. Über populistische Rhetorik, Paderborn ,Wilhelm Fink-Verlag

Panizza, F (2005). Populism and The Mirror of Democracy. New York: Verso Books

Postel, C(2007) : The Populist Vision. Oxford University Press: Oxford New York..

Priester, K (2012): Wesensmerkmale des Populismus Available at: http://www.bpb.de/apuz/75848/wesensmerkmale-despopulismus?p=all (Accessed:21/09/2018)

Ranciere, Jacques (2017) Attacks on "populism" seek to enshrine the idea that there is no alternative Available at : https://www.versobooks.com/blogs/3193-attacks-on-populism-seek-to-enshrine-the-idea-that-there-is-noalternative (Accessed: 31/1/2018)

Rico, G / Guinjoan, M/ Anduiza, E (2017) : The Emotional Underpinnings of Citizens' Populism: How Anger, Fear, and Sadness Affect Populist Attitudes. Available at: http://evaanduiza.uab.cat/wp-content/uploads/2015/07/RicoGuinjoan-Anduiza-2017-Emotions-Populism-web.pdf (Accessed: 21/09/2018)

Rosanvallon, P(2011) :A Reflection on Populism. Available at: https://booksandideas.net/A-Reflection-on-Populism.html (Accessed: 20/09/2018)

Rosenthal, L (2016): Trump, The Tea Party, The Republicans and the Other. Available at: http://www.otheringandbelonging.org/trump-the-tea-party-the-republicans-and-the-other/ (Accessed: 15/09/2018)

Roth, K ( 2017): The Dangerous Rise of Populism Global Attacks on Human Rights Values Available at: https://www.hrw.org/world-report/2017/country-chapters/dangerous-rise-of-populism (Accessed: 30/01/2018)

Shäfer, A / Streeck, W eds, (2013): Politics in the Age of Austerity, Cambridge: Polity .

Special Eurobarometer 413 (2014).Future of Europe. European Commission. Available at: http:/lec.europa.eu /public_opinion/index_en.htm (Accessed: 29.1.2017)

Streeck, W (2017) The Return of the Repressed. New Left Review 104, March-April ,pp 5-18

Taggart, P. A (2002) "Populism and the Pathology of Representative Politics." In Y. Mény and Y. Surel, eds., Democracies and the Populist Challenge, 62-80. Basingstoke: Palgrave.

Van Kessel, S. (2016): Like a Hurricane? The 'winds of populism' in contemporary Europe. In: Morlok, M. , Poguntke, T. and Zons, G. (eds.) Etablierungschancen Neuer Parteien, Baden-Baden, Germany: Nomos, pp. 145-162.

Urbinati, N. (2014). Democracy Disfigured. Opinion, Truth, and the People. Cambridge: Harvard University Press

Verhoeven, I /Duyvendak, J.W (2015): Enter emotions. Appealing to anxiety and anger in a process of municipal amalgamation, Critical Policy Studies, Institute of Local Government Studies, University of Birmingham , Routledge, pp 1-18.

Vittori, D. (2017). Re-conceptualizing populism: Bringing a multifaceted concept within stricter borders. Revista Española de Ciencia Política, 44, 43-65

Vittorio, M (2017) : Can Populism be an ally of Democracy ? Online International Journal of Philosophy November, Year XII N. 24. Available at: http://www.metabasis.it/articoli/24/24_Vittorio.pdf (Accessed: 10/09/2018)

Wißmann, C (2016):Willkommen in der postfaktischen Welt Available at : https://www.cicero.de/kultur/politik-undwahrheit-willkommen-in-der-postfaktischen-welt (Accessed; 28/01/2

Woo,J./ Bova,E. / Kinda,T/ Sophia Zhang, Y (2013), Distributional Consequences of Fiscal Consolidation and the Role of Fiscal Policy: What Do the Data Say?', IMF Working paper 13/195. 
Open Access

This article is distributed under the terms of the Creative Commons Attribution Noncommercial License which permits any noncommercial use, distribution, and reproduction in any medium, provided the original author(s) and source are credited. 